\title{
The Corrosion Behavior of Amorphous Ni-Cr-Ta-P and Ni-Cr-Mo-P Alloys in a Hot Concentrated Phosphoric Acid
}

\author{
Akira Mitsuhashi*, Asahi Kawashima**, Katsuhiko Asami** \\ and Koji Hashimoto** \\ * Central Research Institute, Mitsubishi Metal Corporation \\ ** Institute for Materials Research, Tohoku University
}

\begin{abstract}
The corrosion behavior of amorphous $\mathrm{Ni}-15 \mathrm{Cr}-\mathrm{Ta}-17 \mathrm{P}$ and $\mathrm{Ni}-38 \mathrm{Cr}-20 \mathrm{Mo}-10 \mathrm{P}$ alloys in a $63 \% \mathrm{P}_{2} \mathrm{O}_{5}\left(87 \% \mathrm{H}_{3} \mathrm{PO}_{4}\right)$ solution at $433 \mathrm{~K}$ was investigated. The corrosion rate of the $\mathrm{Ni}-15 \mathrm{Cr}-$ $3 \mathrm{Ta}-17 \mathrm{P}$ alloy was about $0.109 \mathrm{gh}^{-1} \mathrm{~m}^{-2}$ which was one order of magnitude as high as that of the crystalline tantalum metal. The surface film was composed of a high concentration of phosphate and the significant deficiency of nickel took place in both the surface film and the underlying alloy surface. The amorphous $\mathrm{Ni}-38 \mathrm{Cr}-20 \mathrm{Mo}-10 \mathrm{P}$ alloy passivated spontaneously and its corrosion rate was about $0.040 \mathrm{gh}^{-1} \mathrm{~m}^{-2}$. The passive film on the spontaneously passive alloy consisted mainly of hydrated oxyhydroxide of chromium and molybdenum, and the composition of the underlying alloy surface was not greatly different from the bulk alloy composition.
\end{abstract}

Key words: corrosion, phosphoric acid, Ni base alloy, amorphous, surface film, XPS

\section{Introduction}

Amorphous alloys have been found to possess various unique and attractive properties, including an extremely high corrosion-resistance. Even in hot concentrated hydrochloric acids, some of the amorphous alloys become spontaneously passive ${ }^{1}$.

Concentrated phosphoric acids are not strongly oxidizing media and contain no aggressive halogens. Nevertheless, hot concentrated phosphoric acids are quite corrosive at atmospheric pressure in which almost all conventional metallic materials are severely corroded, mainly because of high boiling points and high concentrations. According to Mukai et al.$^{2) \sim 4}$ only tantalum metal is corrosion-resistant among metallic materials in hot concentrated phosphoric acids (72 and 85 weight $\% \mathrm{P}_{2} \mathrm{O}_{5}$ ) which contain pyroand polyphosphoric acids together with orthophosphoric acid ${ }^{5)}$. A comparison of corrosion rates between commercial stainless steels and nickel-base alloys containing chromium in these phosphoric acids exhibits that the nickel base alloys are more corrosion-resistant than stainless

* 1-297 Kitabukuro-cho, Omiya, 330 Japan.

** 2-1-1, Katahira, Sendai, 980 Japan. steels ${ }^{2) \sim 4)}$.

On the other hand, phosphoric acids are composed of orthophosphoric acid and water up to 66 weight $\% \quad \mathrm{P}_{2} \mathrm{O}_{5}{ }^{5)}$. It has been known that "wet phosphoric acids" containing water are more aggressive than "dry phosphoric acids" containing pyro-and poly-phosphoric acids without water at a constant high temperature, particularly, for intergranular corrosion of sensitized austenitic stainless steels ${ }^{6)}$. The present authors ${ }^{7)}$ have investigated the corrosion behavior of amorphous $\mathrm{Ni}-\mathrm{Ta}, \mathrm{Ni}-\mathrm{Ta}-\mathrm{P}, \mathrm{Ni}-\mathrm{Cr}-\mathrm{P}$ and $\mathrm{Ni}-$ Mo-P alloys in a $63 \% \mathrm{P}_{2} \mathrm{O}_{5}\left(87 \% \mathrm{H}_{3} \mathrm{PO}_{4}\right)$ solution at $433 \mathrm{~K}$. The Ni-Ta alloys exhibit very low corrosion rates which are lower than the corrosion rate of tantalum metal by a factor of about ten. The addition of tantalum, chromium or moly-bdenum to amorphous nickel-phosphorus alloys is also beneficial.

In the present work the effect of a combined addition of chromium and molybdenum or chromium and tantalum on the corrosion behavior of amorphous nickel-phosphorus alloys in a hot concentrated phosphoric acid has been studied by using amorphous alloys having a relatively high corrosion resistance. The corrosion be- 
havior has been investigated by immersion test, polarization measurement and XPS analysis.

\section{Experimental Methods}

Alloy ingots were prepared by induction melting of commercial metals and nickel phosphide under an argon atmosphere. The rotating wheel method, in which the copper wheel of $300 \mathrm{~mm}$ diameter was rotated at about $2,500 \mathrm{rpm}$, was used for the preparation of amorphous alloys of about $1 \mathrm{~mm}$ width and $20 \sim 30 \mu \mathrm{m}$ thickness. Prior to corrosion and electrochemical measurements alloy specimens were polished mechanically with silicon carbide paper up to No. 1000 in cyclohexane.

A solution used was a $63 \% \mathrm{P}_{2} \mathrm{O}_{5}\left(87 \% \mathrm{H}_{3} \mathrm{PO}_{4}\right)$ solution at $433 \mathrm{~K}$. The corrosion rate was estimated from the weight loss after immersion for about $360 \mathrm{ks}$. After immersion or potentiostatic polarization, X-ray photoelectron spectra from the specimens were measured by SHIMADZU-ESCA 850 electron spectrometer with $\mathrm{Mg} \mathrm{K} \alpha$ excitation $(1253.6 \mathrm{eV})$. The binding energies of the electrons were calibrated by the method described elsewhere ${ }^{8), 9}$. The composition and thickness of the surface film and the composition of the substrate alloy immediately under the surface film were quantitatively determined by the previously proposed method ${ }^{10), 11}$.

The quantitative determination ${ }^{12)}$ was carried out using the assumption of three-layer model of the outermost contaminant hydrocarbon layer of uniform thickness, the surface film of uniform thickness and the underlying alloy of $\mathrm{X}$ ray photoelectron spectroscopically infinite thickness and the assumption of a homogeneous distribution of constituents in each layer. The photo-ionization cross-sections relative to the $\mathrm{O}$ ls electrons used have been summarized elsewhere ${ }^{12)}$, except for that of $\mathrm{Ta} 4 \mathrm{f}$ electrons of 3.18 which has been estimated from the photoionization cross-sections calculated theoretically by Scofield ${ }^{13)}$. The measured spectrum of an element was separated into spectra originating from respective components of different valences as described previously ${ }^{14)}$.

\section{Results and Discussion}

After immersion for $360 \mathrm{ks}$ in the $63 \% \quad \mathrm{P}_{2} \mathrm{O}_{5}$ solution at $433 \mathrm{~K}$ the amorphous $\mathrm{Ni}-15 \mathrm{Cr}-3$ Ta-17 $\mathrm{P}^{*}$ alloy maintained the metallic luster

*1) The number in an alloy formula denotes the concentration of the element in atomic percent.

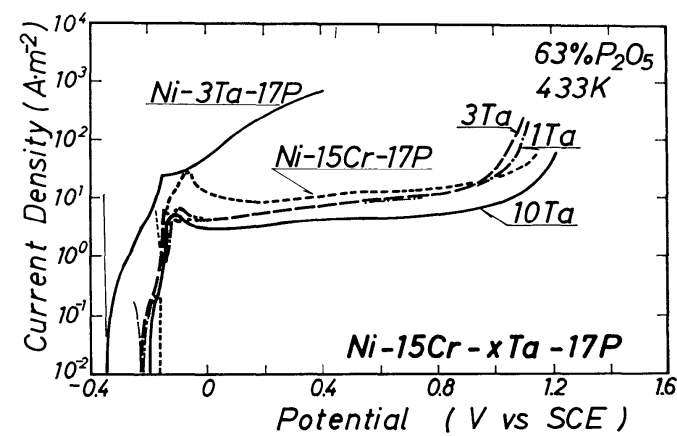

Fig. 1 Polarization curves of amorphous $\mathrm{Ni}-$ 15Cr-Ta-17P and $\mathrm{Ni}-3 \mathrm{Ta}-17 \mathrm{P}$ alloys measued in a $63 \% \mathrm{P}_{2} \mathrm{O}_{5}\left(87 \% \mathrm{H}_{3} \mathrm{PO}_{4}\right)$ solution at $433 \mathrm{~K}$.

although the surface became very slightly yellowish. The corrosion rate of the amorphous $\mathrm{Ni}-15 \mathrm{Cr}-3 \mathrm{Ta}-17 \mathrm{P}$ alloy was about $0.109 \mathrm{gh}^{-1}$ $\mathrm{m}^{-2}$. This corrosion rate was slightly lower than that of $0.152 \mathrm{gh}^{-1} \mathrm{~m}^{-2}$ for the Ni-3Ta-17P alloy, but is almost the same as that of $0.105 \mathrm{gh}^{-1}$ $\mathrm{m}^{-2}$ for the $\mathrm{Ni}-15 \mathrm{Cr}-17 \mathrm{P}$ alloy and is about one order of magnitude higher than $0.024 \mathrm{gh}^{-1} \mathrm{~m}^{-2}$ for the crystalline tantalum metal.

The Ni-38 Cr-20 Mo-10 P alloy maintained the metallic luster after immersion for $360 \mathrm{ks}$ in the $63 \% \mathrm{P}_{2} \mathrm{O}_{5}$ solution at $433 \mathrm{~K}$, and its corrosion rate was about $0.040 \mathrm{gh}^{-1} \mathrm{~m}^{-2}$. Fig. 1 shows anodic polarization curves of amorphous $\mathrm{Ni}$ 15Cr-Ta-17P and Ni-3Ta-17P alloys. The open circuit potentials of these alloys located in the active region and became almost steady at about $-0.22 \mathrm{~V}$ (SCE) after immersion for about $600 \mathrm{~s}$. These alloys tend to exhibit an active-topassive transition by polarization. The addition of a small amount of tantalum decreases current densities in both the active and passive regions. Since the Ni-3Ta-17P alloy is hardly passivated, the decrease in the current densities in both the active and passive regions is due to the effect of the combined addition of chromium and tantalum.

Fig. 2 shows potentiostatic and potentiodynamic polarization curves of amorphous $\mathrm{Ni}-38 \mathrm{Cr}$ $20 \mathrm{Mo}-10 \mathrm{P}$ alloy. Although the potentiodynamic polarization curve measured starting from the cathodic region exhibits a clear active dissolution peak, the potentiostatic polarization curve reveals that spontaneous passivation occurs on this high chromium and high molybdenum alloy. The difference in the passivating ability between the $\mathrm{Ni}-15 \mathrm{Cr}-\mathrm{Ta}-17 \mathrm{P}$ and $\mathrm{Ni}-38 \mathrm{Cr}-20 \mathrm{Mo}-10 \mathrm{P}$ alloys is consistent with the fact that the corro- 


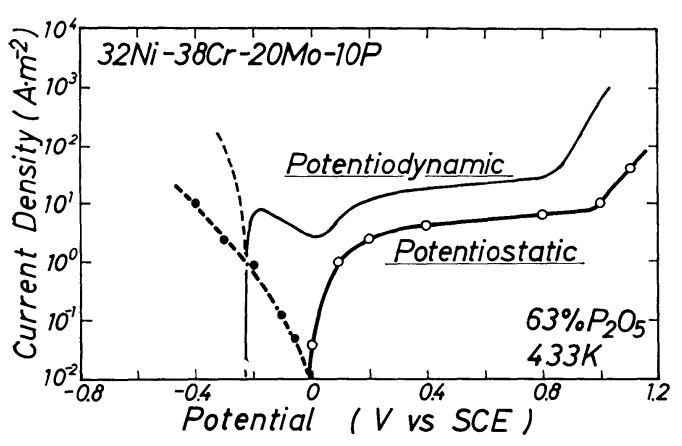

Fig. 2 Potentiodynamic and potentiostatic polarization curves of amorphous $\mathrm{Ni}-38 \mathrm{Cr}-$ $20 \mathrm{Mo}-10 \mathrm{P}$ alloy measured in a $63 \% \mathrm{P}_{2} \mathrm{O}_{5}$ $\left(87 \% \mathrm{H}_{3} \mathrm{PO}_{4}\right)$ solution at $433 \mathrm{~K}$.

sion resistance of the amorphous $\mathrm{Ni}-38 \mathrm{Cr}-$ 20Mo-10P alloy is better than that of the amorphous $\mathrm{Ni}-15 \mathrm{Cr}-\mathrm{Ta}-17 \mathrm{P}$ alloys.

For a better understanding of the corrosion and passivating behavior, an XPS analysis was carried out after immersion or potentiostatic polarization in the $63 \% \mathrm{P}_{2} \mathrm{O}_{5}$ solution at $433 \mathrm{~K}$.

The spectra over the wide binding energy region showed peaks of oxygen and carbon in addition to those of alloy constituents. The $\mathrm{C}$ is spectrum found arose from a contaminant hydrocarbon layer covering the specimen surface ${ }^{15}$. All the spectra from alloy constituents were composed of superposed two spectra corresponding to the oxidized state (OX) in the surface film and the metallic state $(M)$ in the alloy surface immediately under the surface film. The binding energies of oxidized and metallic states of $\mathrm{Ni} 2 \mathrm{p}_{3 / 2}, \mathrm{Cr} 2 \mathrm{p}_{3 / 2}$ and $\mathrm{P} 2 \mathrm{p}$ electrons were not different between $\mathrm{Ni}-38 \mathrm{Cr}-20 \mathrm{Mo}-10 \mathrm{P}$ and $\mathrm{Ni}$ 15Cr-3Ta-17P alloys. The peak binding energies of $\mathrm{Ni}^{\mathrm{M}} 2 \mathrm{p}_{3 / 2}$ and $\mathrm{Ni}^{\mathrm{Ox}} 2 \mathrm{p}_{3 / 2}$ electrons were about 853.1 and $856.5 \mathrm{eV}$, respectively, and hence the nickel ion in the surface film is assigned to $\mathrm{Ni}^{2+}$ ion.

The $\mathrm{Cr}^{\mathrm{M}} 2 \mathrm{p}_{3 / 2}$ and $\mathrm{Cr}^{\mathrm{Ox}} 2 \mathrm{p}_{3 / 2}$ electrons gave peaks at about 574.1 and $577.7 \mathrm{eV}$, respectively. The $\mathrm{Cr}^{\circ \mathrm{Xx}} 2 \mathrm{p}_{3 / 2}$ electrons arose from the $\mathrm{Cr}^{3+}$ ion in the surface film although the binding energy of the $\mathrm{Cr}^{\mathrm{Ox}} 2 \mathrm{p}_{3 / 2}$ electrons is larger than those from stable passive hydrated chromium oxyhydroxide films on amorphous chromium-containing alloys (about $577.5 \mathrm{eV})^{16)}$ and on binary $\mathrm{Fe}-\mathrm{Cr}$ alloys $(572.5 \mathrm{eV})^{17)}$ and from $\mathrm{Cr}(\mathrm{OH})_{3}$. $0.4 \mathrm{H}_{2} \mathrm{O}(577.03 \mathrm{eV})^{18)}$.

The $P 2 p$ electrons exhibited two peaks at about 129.6 and $133.8 \mathrm{eV}$, respectively. The lat- ter is assigned to $\mathrm{P}^{5+}$ in phosphate in the surface film $^{18)}$. The former is assumed to arise from phosphorus in the underlying alloy, but the binding energy is about $0.5 \mathrm{eV}$ lower than that of red phosphorus ${ }^{20)}$ due possibly to charge transfer from metal atoms to the phosphorus atom in amorphous alloys.

The most intense photoelectron of Mo is the Mo $3 d_{5 / 2}$ electron. However, the peak of the $\mathrm{Mo}^{\mathrm{M}} 3 \mathrm{~d}_{5 / 2}$ electrons overlapped the $\mathrm{Mo}^{\mathrm{ML}} 3 \mathrm{~d}_{3 / 2}$ electrons, and hence the qualitative and quantitative determinations were carried out by using the $\mathrm{Mo}^{\mathrm{M}} 3 \mathrm{~d}_{5 / 2}$ electrons and the $\mathrm{Mo}^{\mathrm{Ox}} 3 \mathrm{~d}_{3 / 2}$ electrons. The Mo $3 \mathrm{~d}$ spectrum measured was composed of superposed two spectra, and showed peaks of the $\mathrm{Mo}^{\mathrm{M}} 3 \mathrm{~d}_{5 / 2}$ electrons and the $\mathrm{Mo}^{\mathrm{Ox}}$ $3 \mathrm{~d}_{3 / 2}$ electrons at about 227.8 and $235.8 \mathrm{eV}$, respectively. The $\mathrm{Mo}^{\mathrm{ox}}$ was assigned to $\mathrm{Mo}^{6+}$ in the surface film ${ }^{21)}$.

The $\mathrm{Ta} 4 \mathrm{f}_{7 / 2}$ electrons showed peaks at about 23.1 and $26.7 \mathrm{eV}$. These were assigned to metallic and pentavalent tantalum, respectively. The $\mathrm{Ta}^{\mathrm{M}} 4 \mathrm{f}_{7 / 2}$ peak was shifted about $1.2 \mathrm{eV}$ higher binding energy in comparison to that of crystalline tantalum metal. This is reasonable since the binding energy of the $\mathrm{Ta}^{\mathrm{MI}} 4 \mathrm{f}_{7 / 2}$ electrons in $\mathrm{Ni}-$ Ta alloys increase with decreasing tantalum content like 21.8, 22.4 and $22.5 \mathrm{eV}$ for tantalum metal, amorphous $\mathrm{Ni}-50 \mathrm{Ta}$ alloy and amorphous $\mathrm{Ni}-40 \mathrm{Ta}$ alloy, respectively ${ }^{22)}$. The increase in the binding energy of the $\mathrm{Ta}^{\mathrm{M}} 4 \mathrm{f}_{7 / 2}$ electrons is due possibly to charge transfer from tantalum atom to nickel atom in the alloys, since the binding energy of the $\mathrm{Ni} 2 \mathrm{p}_{3 / 2}$ electrons in the $\mathrm{Ni}-\mathrm{Ta}$ alloy decrease with increase in alloy tantalum content, like $852.6^{20)}, 852.5^{22)}$ and $852.3^{22)} \mathrm{eV}$ for nickel metal, amorphous $\mathrm{Ni}-40 \mathrm{Ta}$ alloy and amorphous $\mathrm{Ni}-50 \mathrm{Ta}$ alloy.

The $\mathrm{O}$ is spectrum was significantly broad since it arose from oxygen in $\mathrm{O}^{2-}, \mathrm{OH}^{-}, \mathrm{PO}_{4}{ }^{3-}$ and $\mathrm{H}_{2} \mathrm{O}$.

After integrated intensities of photoelectron spectra were separately obtained for individual species, the quantitative determination of the thickness and composition of the surface film and the composition of the underlying alloy surface was performed.

The thickness of the surface film formed on the amorphous $\mathrm{Ni}-15 \mathrm{Cr}-3 \mathrm{Ta}-17 \mathrm{P}$ alloy in the $63 \% \mathrm{P}_{2} \mathrm{O}_{5}$ solution at $433 \mathrm{~K}$ was $2.7-3.2 \mathrm{~nm}$ and was almost independent of the immersion time. Fig. 3 shows the change in cationic fractions in the surface film formed on the amorphous $\mathrm{Ni}$ - 


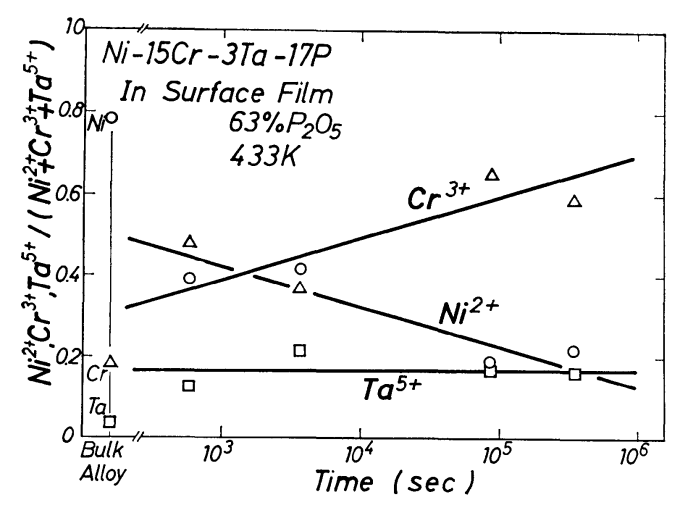

Fig. 3 Ratios of cations to the sum of $\mathrm{Ni}^{2+}, \mathrm{Cr}^{3+}$ and $\mathrm{Ta}^{5+}$ ions in the surface film formed on an amorphous $\mathrm{Ni}-15 \mathrm{Cr}-3 \mathrm{Ta}-17 \mathrm{P}$ alloy by immersion for different time intervals in a $63 \% \mathrm{P}_{2} \mathrm{O}_{5}\left(87 \% \mathrm{H}_{3} \mathrm{PO}_{4}\right)$ solution at $433 \mathrm{~K}$.

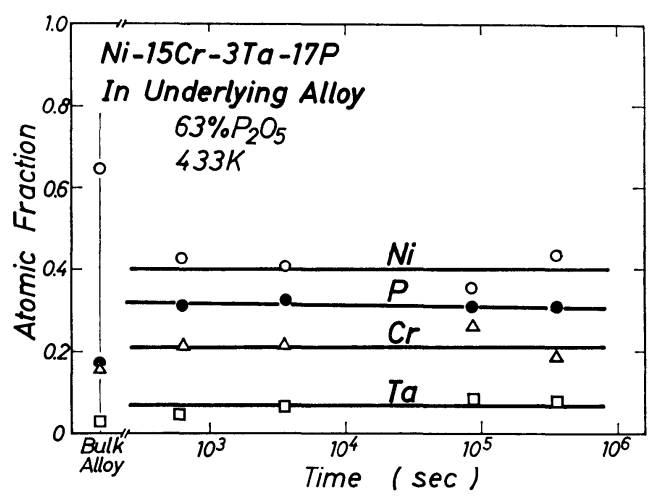

Fig. 4 Atomic fractions of the amorphous $\mathrm{Ni}$ 15Cr-3Ta-17P alloy surface just below the surface film formed by immersion for different time intervals in a $63 \% \quad \mathrm{P}_{2} \mathrm{O}_{5}$ $\left(87 \% \mathrm{H}_{3} \mathrm{PO}_{4}\right)$ solution at $433 \mathrm{~K}$.

$15 \mathrm{Cr}-3 \mathrm{Ta}-17 \mathrm{P}$ alloy with time of immersion in the $63 \% \mathrm{P}_{2} \mathrm{O}_{5}$ solution at $433 \mathrm{~K}$.

The cationic fractions are ratios of $\mathrm{Ni}^{2+}, \mathrm{Cr}^{3+}$ and $\mathrm{Ta}^{5+}$ to their sum in the surface film. The concentration of chromic ion after $600 \mathrm{~s}$ immersion is more than twice as high as the chromium concentration of the bulk alloy, and the concentration of chromic ion tends to increase with immersion time. The concentration of tantalum ion is 3 or 4 times as high as that of tantalum in the bulk alloy. By contrast, nickel is quite deficient in the surface film and apt to decrease with time of immersion. As mentioned above $\mathrm{P}^{5+}$ constitutes $\mathrm{PO}_{4}{ }^{3-}$ ion. The phosphate content in the film is very high. For example the negative charge of phosphate ranged

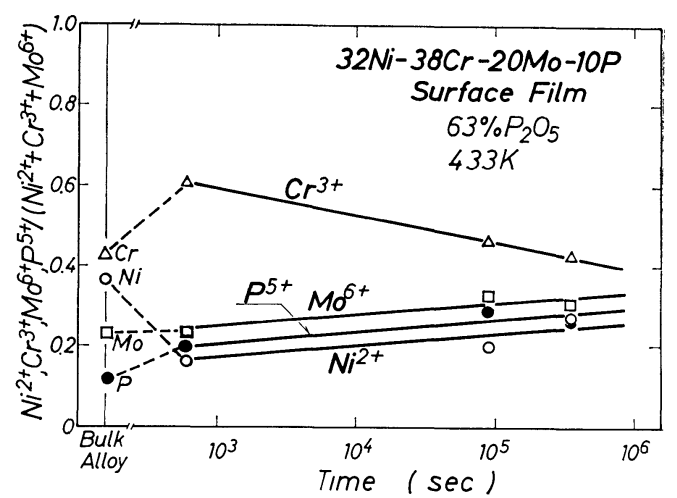

Fig. 5 Ratios of cations to the sum of $\mathrm{Ni}^{2+}, \mathrm{Cr}^{3+}$ and $\mathrm{Mo}^{6+}$ ions in the surface film formed on an amorphous $\mathrm{Ni}-38 \mathrm{Cr}-20 \mathrm{Mo}-17 \mathrm{P}$ alloy by immersion for different time intervals in a $63 \% \mathrm{P}_{2} \mathrm{O}_{5}\left(87 \% \mathrm{H}_{3} \mathrm{PO}_{4}\right)$ solution at $433 \mathrm{~K}$.

from a half to two thirds of total negative charges in the film, although the film includes $\mathrm{O}^{2-}, \mathrm{OH}^{-}$and $\mathrm{H}_{2} \mathrm{O}$. Accordingly, the surface film consists of a mixture of hydrated oxyhydroxide and phosphate of chromium and tantalum.

Fig. 4. shows the atomic fractions in the amorphous $\mathrm{Ni}-15 \mathrm{Cr}-3 \mathrm{Ta}-17 \mathrm{P}$ alloy surface just below the surface film. Prior to immersion, mechanical polishing was carried out in cyclohexane, and the underlying alloy composition of the mechanically polished specimen is nearly the same as the bulk alloy composition. After immersion the underlying alloy is significantly deficient with nickel with consequent enrichments of phosphorus, chromium and tantalum. Because nickel was also deficient in the surface film, nickel is unstable in this aggressive hot concentrated phosphoric acid, and hence a preferential dissolution of nickel results in enrichments of chromium, tantalum and phosphorus in both the surface film and the underlying alloy surface.

Fig. 5 shows the cationic fractions of the surface films on the amorphous $\mathrm{Ni}-38 \mathrm{Cr}-20 \mathrm{Mo}-$ $10 \mathrm{P}$ alloy as a function of time of immersion in the $63 \% \mathrm{P}_{2} \mathrm{O}_{5}$ solution at $433 \mathrm{~K}$. Nickel is significantly deficient in the surface film, and chromium, molybdenum and phosphorus are concentrated. The negative charge of phosphate ion in the surface film is about one fifth of the total negative charges, and hence the major species in the surface film are hydrated oxyhydroxides of chromium, molybdenum and nickel. Prolonged immersion decreases the con- 


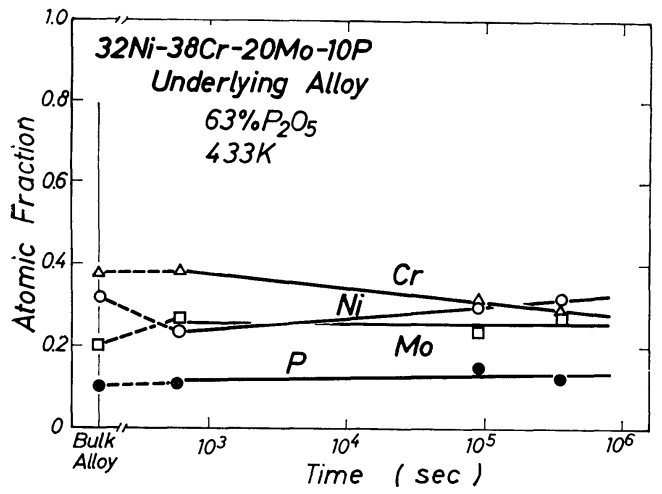

Fig. 6 Atomic fractions of the amorphous $\mathrm{Ni}-$ 38Cr-20Mo-17P alloy surface just below the surface film formed by immersion for different time intervals in a $63 \% \mathrm{P}_{2} \mathrm{O}_{5}$ $\left(87 \% \mathrm{H}_{3} \mathrm{PO}_{4}\right)$ solution at $433 \mathrm{~K}$.

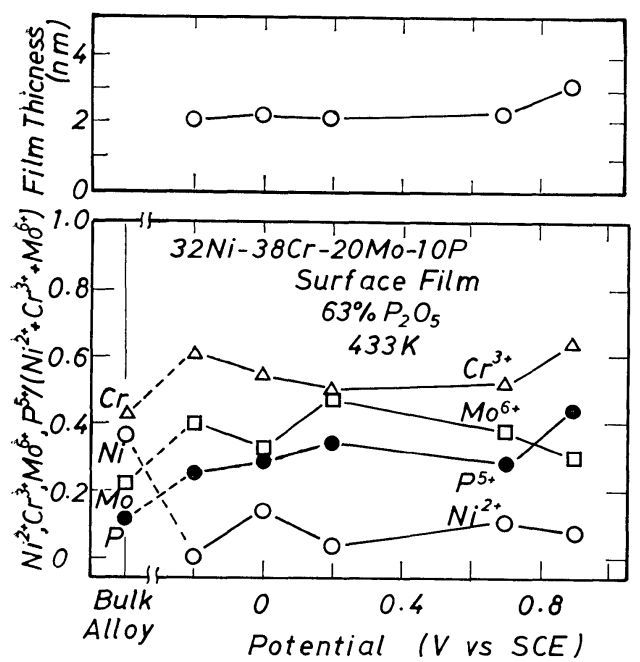

Fig. 7 Ratios of cations to the sum of $\mathrm{Ni}^{2+}, \mathrm{Cr}^{3+}$ and $\mathrm{Mo}^{6+}$ ions in the surface film and the thickness of the surface film formed on an amorphous $\mathrm{Ni}-38 \mathrm{Cr}-20 \mathrm{Mo}-10 \mathrm{P}$ alloy by potentiostatic polarization at various potentials in a $63 \% \quad \mathrm{P}_{2} \mathrm{O}_{5} \quad\left(87 \% \quad \mathrm{H}_{3} \mathrm{P}_{4}\right)$ solution at $433 \mathrm{~K}$.

centration of chromic ion in the surface film and results in the formation of the surface film whose cationic fractions are not very different from the bulk alloy composition.

Fig. 6 shows the atomic fraction in the alloy surface immediately under the surface film formed on the amorphous $\mathrm{Ni}-38 \mathrm{Cr}-20 \mathrm{Mo}-10 \mathrm{P}$ alloy in the $63 \% \mathrm{P}_{2} \mathrm{O}_{5}$ solution at $433 \mathrm{~K}$. The concentration of individual element is not the same as the bulk alloy composition, but the difference between analyzed and bulk alloy con-

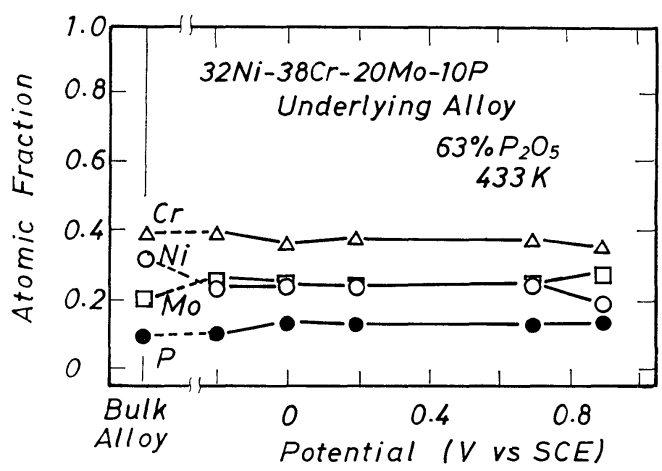

Fig. 8 Atomic fractions of the amorphous $\mathrm{Ni}$ $38 \mathrm{Cr}-20 \mathrm{Mo}-17 \mathrm{P}$ alloy surface just below the surface film formed by potentiostatic polarization at various potentials in a $63 \%$ $\mathrm{P}_{2} \mathrm{O}_{5}\left(87 \% \mathrm{H}_{3} \mathrm{PO}_{4}\right)$ solution at $433 \mathrm{~K}$.

centrations is not very large.

Fig. 7 shows the cationic fractions of the surface film and the thickness of the surface film formed on the amorphous $\mathrm{Ni}-38 \mathrm{Cr}-20 \mathrm{Mo}-$ $10 \mathrm{P}$ alloy by potentiostatic polarization for $600 \mathrm{~s}$ in the $63 \% \mathrm{P}_{2} \mathrm{O}_{5}$ solution at $433 \mathrm{~K}$ as a function of polarization potential. The film thickness was about $2 \mathrm{~nm}$ up to $700 \mathrm{mV}$ (SCE) and is increased to about $3 \mathrm{~nm}$ at $900 \mathrm{mV}$ (SCE). Nickel is considerably deficient in the surface film with consequent enrichments of chromium, molybdenum and phosphorus. The negative charge of phosphate ion in the surface film was about $20 \%$ of the total negative charges up to $700 \mathrm{mV}$ (SCE). Accordingly, the major constituents of the surface film are hydrated oxyhydroxides of chromium and molybdenum, and chromium phosphate is increased at $900 \mathrm{mV}$ (SCE).

The composition of the alloy surface immediately under the surface film after potentiostatic polarization is given in Fig. 8. Nickel is less than three quarters of the bulk composition and hence all other constituents are slightly concentrated. The degree of nickel deficiency in the surface of the amorphous $\mathrm{Ni}-38 \mathrm{Cr}-20 \mathrm{Mo}-$ 10P alloy is not as large as that found in the surface of the amorphous $\mathrm{Ni}-15 \mathrm{Cr}-3 \mathrm{Ta}-17 \mathrm{P}$ alloy immersed in the same phosphoric acid. This suggests the better corrosion resistance of the $\mathrm{Ni}-38 \mathrm{Cr}-20 \mathrm{Mo}-10 \mathrm{P}$ alloy than the amorphous $\mathrm{Ni}-15 \mathrm{Cr}-3 \mathrm{Ta}-17 \mathrm{P}$ alloy as has been found by the corrosion test.

\section{Conclusions}

The corrosion behavior of amorphous Ni- 
15Cr-Ta-17P and $\mathrm{Ni}-38 \mathrm{Cr}-20 \mathrm{Mo}-10 \mathrm{P}$ alloys in a $63 \% \mathrm{P}_{2} \mathrm{O}_{5}$ solution at $433 \mathrm{~K}$ was studied by immersion test, electrochemical measurement and XPS analysis. The corrosion rate of amorphous $\mathrm{Ni}-15 \mathrm{Cr}-3 \mathrm{Ta}-17 \mathrm{P}$ alloy was $0.109 \mathrm{gh}^{-1}$ $\mathrm{m}^{-2}$ which was almost one order of magnitude higher than that of crystalline tantalum metal. The open circuit potentials of amorphous $\mathrm{Ni}-$ $15 \mathrm{Cr}-\mathrm{Ta}-17 \mathrm{P}$ alloys containing $0 \sim 10$ at $\%$ tantalum were in the active region. The amorphous $\mathrm{Ni}-38 \mathrm{Cr}-20 \mathrm{Mo}-10 \mathrm{P}$ alloy passivated spontaneously and its corrosion rate was $0.040 \mathrm{gh}^{-1} \mathrm{~m}^{-2}$. The XPS analysis revealed that the significant deficiency of nickel took place in both the surface film and the underlying alloy surface of the amorphous $\mathrm{Ni}-15 \mathrm{Cr}-3 \mathrm{Ta}-17 \mathrm{P}$ alloy after immersion with consequent enrichments of chromium, tantalum and phosphorus. The surface film formed on the $\mathrm{Ni}-15 \mathrm{Cr}-3 \mathrm{Ta}-17 \mathrm{P}$ alloy by immersion consisted of a mixture of hydrated oxyhydroxide and phosphate of chromium and tantalum in which the negative charge of phosphate comprised a half to two thirds of the total negative charges in the surface film. The composition of the alloy surface under the passive film of the spontaneously passive $\mathrm{Ni}-38 \mathrm{Cr}-$ 20Mo-10P alloy was not significantly different from the composition of the bulk alloy in accord with the better corrosion resistance, and the passive film was composed mainly of hydrated oxyhydroxide containing both chromium and molybdenum.

The present work is supported in part by Grant-in-Aid for Developmental Scientific Research No. 61850127 from the Ministry of Education, Science and Culture.

(Received June 16, 1987)

\section{References}

1) K. Hashimoto, K. Kobayashi, K. Asami \& T. Masumoto: Proc. 8th Int. Cong. Metallic Corrosion, p. 70. DECHEMA, Frankfurt (1981).

2) M. Mukai, T. Saji \& T. Washizuka: J. Metal Finishing Soc. Japan, 13, 396 (1962).
3) M. Mukai, T. Saji \& T. Washizuka: J. Metal Finishing Soc. Japan, 14, 24 (1963).

4) M. Mukai \& T. Saji: J. Metal Finishing Soc. Japan, 14, 401 (1963).

5) S. Ohashi \& H. Sugatani: Bull. Chem. Soc. Japan, 30, 864 (1957).

6) M. Okubo: Corros. Engineering (Boshoku Gijutsu), 34, 623 (1985).

7) A. Mitsuhashi, K. Asami, A. Kawashima \& K. Hashimoto, Corros. Sci., 27, 957 (1987).

8) K. Asami: J. Electron Spectrosc., 9, 469 (1976).

9) K. Asami \& K. Hashimoto: Corros. Sci., 17, 559 (1977).

10) K. Asami \& K. Hashimoto: Corros. Sci., 17, 713 (1977).

11) K. Asami \& K. Hashimoto: Corros. Sci., 24, 83 (1984).

12) K. Hashimoto \& K. Asami: Corros. Engineering (Boshoku Gijutsu), 26, 375 (1977).

13) J. H. Scofield: J. Electron Spectrosc., 8, 129 (1976).

14) K. Asami, K. Hashimoto \& S. Shimodaira: Corros. Sci., 16, 387 (1976).

15) K. Siebahn, C. Nordling, A. Fahlman, R. Nordberg, K. Hamrin, J. Hedman, G. Johansson, T. Bergmark, S.-E. Karlsson, I. Lindgren \& B. Lindberg: "ESCA-Atomic, Molecular, and Solid State Structure Studied by Means of Electron Spectroscopy", Almqvist and Wikells AB, Stockholm (1967).

16) K. Hashimoto, K. Asami \& A. Kawashima: Proc. 9th Int. Cong. Metallic Corrosion, National Research Council of Canada, Ottawa (1984), Vol. I, p. 208.

17) K. Asami, K. Hashimoto \& S. Shimodaira: Corros. Sci., 18, 151 (1978).

18) K. Asami \& K. Hashimoto: Corros. Sci., 17, 559 (1977).

19) M. Pelavin, D. N. Hendrickson, J. M. Hollander \& W. I. Jolly: J. Phys. Chem., 74, 1116 (1970).

20) K. Asami, H. M. Kimura, K. Hashimoto, T. Masumoto, A. Yokoyama, H. Komiyama \& H. Inoue: J. Non-Cryst. Solids, 64, 149 (1984).

21) K. S. Kim, W. E. Baitinger, J. W. Amy \& N. W. Winograd: J. Electron Spectrosc., 5, 351 (1974).

22) A. Mitsuhashi, K. Asami \& K. Hashimoto: unpublished data. 